\title{
Church Tradition and Culture: No Admission of Children to the Holy Communion
}

\author{
Ebenhaizer Imanuel Nuban Timo \\ Prodi Ilmu Pendidikan Teologi - FKIP UKAW Kupang \\ E-mail: ebenhur65@yahoo.co.id
}

\begin{abstract}
Abstrak
Penulis mendiskusikan sikap penolakan terhadap kehadiran anak-anak penerima baptisan dalam perayaan Perjamuan Kudus sebagaimana yang dipraktekkan kebanyakan jemaat dalam lingkungan Gereja Kristen Jawa (GKJ). Bertolak dari penelitian terhadap Pokok-Pokok Ajaran (PPA) GKJ, penulis menunjukkan adanya inkonsistensi dalam penerapan PPA-GKJ. Pada satu sisi GKJ memahami Perjamuan Kudus sebagai perlambang kehidupan keluarga Allah. Tetapi pada sisi lain, anak-anak penerima baptisan tidak terhisab dalam keluarga Allah sehingga ditolak kehadirannya dalam Perjamuan Kudus. Ada dua penyebab yang melandasi praktek ini. Pertama, penetapan persyaratan yang terlalu tinggi bagi keikut-sertaan dalam Perjamuan Kudus. Kedua, masih kuat pengaruh paham dalam budaya Jawa tradisional tentang anak-anak sebagai kaum yang tidak bisa disetarakan dengan orang dewasa. Perspektif rangkap dari Roberth Schreiter yakni membuka tradisi gereja dan membuka budaya dipakai penulis untuk memperlihatkan bahwa penolakan terhadap anakanak dalam Perjamuan Kudus merupakan tindakan yang bertentangan dengan hakikat Perjamuan Kudus.
\end{abstract}

Kata Kunci: Perjamuan Kudus, Anak-anak, Gereja Kristen di Jawa, Kebudayaan Jawa dan Indonesia

\section{Abstract}

The author discusses the prohibition of entry of baptized children in the celebration of Holy Communion as practiced by most congregations in Christian Church of Java (Gereja Kristen Jawa/ GKJ, Bahasa Indonesia). Drawing from the research conducted on the principle teachings (Pokok-Pokok Ajaran/PPA, Bahasa Indonesia) of GKJ, the author explains that there are inconsistencies in the implementation of PPA-GKJ. On one hand, GKJ understands that the Holy Communion is a symbol of life in God's family. On the other hand, baptized children are not included within God's family, which is the reason why they are not allowed to attend Holy Communion. There are two main reasons why this happens. First, difficult requirement for the permission to attend Holy Communion. Second, strong traditional Javanese ideology to exclude children from adult activities. The author employs Double perspective from Roberth Schreiter to analyze church tradition and culture to show that excluding children from Holy Communion contrasts to the main essence of Holy Communion.

Keywords: Holy Communion, Children, Christian Church of Java, Javanese Culture and Indonesia. 


\section{INTRODUCTION}

There seems to be a reason to say, in the Javanese Protestant church tradition, children are not very important, even though their Bible teachings were welcomed by Jesus' hand. Why it happened, it is important to reveal. Christian Church founded from reformation activism in the $16^{\text {th }}$ Century only includes two sacraments: Baptism and Communion. There are at least three reasons for accepting these two sacraments, which also shows rejection of the other five rites previously made sacred in Catholic Roman Church. The first reason, both sacraments are directly ordered by Jesus Christ (Matias 28:19-20, Lucas 22:19). Second, out of seven sacraments in the Old Church, only two refers directly to the death and resurrection of Jesus Christ. Third, people who believe in the afterlife after the return of Jesus Christ will only experience Baptism and Communion (Lucas 22:16) (Timo, 2016, p. 238).

Christian Church of Java (Gereja Kristen Jawa/ GKJ), as the embodiment of Christ's body along with other Reformist Church only celebrates two sacraments: Baptism and Communion (Sinode, 2005, p. 129). Out of the three reasons mentioned above, the second and third reason are mentioned explicitly in the Principal
Teachings (Pokok-Pokok Ajaran/PPA-GKJ). Even though the first reason is not mentioned, it does not mean that they ignore it. In order to answer question number 128 and 129, the verses used as reference (Matias 28:19-20 and Corinthian I 15:25-26) emphasized that Jesus's command for His followers to celebrate the sacraments is to remember Him. In question number 135, PPA-GKJ presents three answers regarding the function of Communion Sacrament. The second answer emphasizes on the function of Communion Sacrament as the symbol of God's family. This answer, I believe, is considered to be a positive and important entry point to talk about children in Holy Communion Sacrament (paedo-communio).

Commonly, in the practice of these sacraments, Reformist Churches in Indonesia, including GKJ considers Holy Communion Sacrament exclusively for adults, and especially male. ${ }^{1}$ Children or underage congregations (OPUD) are not allowed (in many sinode, baptized children are not allowed) to participate in the Holy Communion even though they are already considered as full-fledged member within Christ's Body through Holy Baptism. In

\footnotetext{
${ }^{1}$ I put an emphasis on the exclusion considering that there are many women who gave birth without holy matrimony, while the men who did not want to be responsible for the pregnancy could waltz into the Holy Communion without any guilt.
} 
GKJ, the exclusion of children is explicitly emphasized in PPA-GKJ, which is in question number 137 of PPA-GKJ: "Who is allowed to participate in Communion Sacrament?" Answer: "Every baptized adult, or who claim to believe and not in special guidance" (Sinode, 2005, p. 137).

It was clear that there is a practice of elitism within GKJ, what I.H. Enkaar calls as sacrament separation, which was conducted in missionary era. In his study to analyze the practice of separatism, Enklaar writes: "Slowly, we see how easy it is to degrade Baptism, and the requirements for acceptance are completely dismissed, and obliterate its original traits. Now, we see the opposite occurring in the Communion: the sanctification of communion and it becomes unreachable for all congregations (Enklaar \& Siahaan, 1978, p. 142).”

The above description generate a statement: "What is wrong with underage congregations that they were excluded from Communion Sacrament, but they are allowed to participate in Baptism?" Is there hierarchy in virtue or sanctity between Baptism and Communion that they need to set high requirement for the participation of this sacrament? This paper is conducted to answer these two questions.

\section{METHOD}

The method used in this research is library one. The main documents under the investigation are the Principal Teachings of Javanese Christian Church (Pokok-Pokok Ajaran/PPA-GKJ) and Javanese Christian Church's Ecclesiology writen by her general secretary. Considerations expressed in those documents are discussed intensively in view of some dogmatics and doctrinal elaborations commonly used by Indonesian Christian congregations and readers.

\section{RESULT AND DISCUSSION}

There are some studies conducted on children's participation in Holy Communion Sacrament. The most detailed study was conducted by Rev. Tabita Kartika Christiani, a lecturer in the Faculty of Theology UKDW, who presented her paper in PWG LPP study Sinode GKJ/ GKI of Central Java on March 22, 2012. There are two distinguishing features between this study and the study conducted by Rev. Tabita. First, Rev. Tabita and other studies conducted biblical-dogmatic mining on children's participation in Holy Communion, which was then used to focus on the exclusion of children from Holy Communion. In other words, they analyzed this topic deductively. In my study, I will 
focus exclusively on inductive route in analyzing PPA-GKJ and its ecclesiology. I want to show that from the doctrinal perspective (PPA-GKJ and GKJ ecclesiology), there is already a room for OPUD participation in Holy Communion Sacrament. If in practice, OPUD participation is not allowed, it is mainly caused by inconsistent points in PPA-GKJ related to its doctrinal principles. In other words, I will conduct a review on PPA-GKJ. My study would be considered somewhat presumptuous because I am not a part of GKJ congregation. I am able to do this based on the consideration written in PPA$\mathrm{GKJ}$, in which in question-answer number 5 that explicitly emphasizes on its openness on critique or correction and renewal of the church's teachings due to two reasons. First, the church teachings are human-made through biblical interpretation that would not escape from human errors. Second, the need to the challenges of dynamic times (Sinode, 2005).

Second, Rev. Tabita conducted a purely biblical or doctrinal theological study. I try to implement in-depth study, which focuses on its cultural aspect, even though I am not a Javanese. I use cultural study because I agree to the conclusion made by Rev. Andreas Untung Wiyono, the
GKJ church synod leader of 2011-2015. On his study of GKJ ecclesiology, Rev. Andreas evoked my imagination on the influence of Javanese culture on the exclusion of children from the sacrament. Holy Communion Sacrament was, as written by Rev. Andreas, "regarding the function of church, if seen from its cultural perspective, shows that culture develops in the society influenced by the government perspective of church as religious institution" (Wiyono, 2008, p. 15). My personal experience being involved in the church also shows many things, including the traits and decisions of the leaders in sacrament celebrations are mainly influenced by cultures rather than Biblical witness regarding Jesus Christ's life and work. In other words, to use Marcus Borg's formula, the church chooses to follow conventional wisdom, taking the wide doors, following the societal habits that it becomes embedded in the church rather than implementing alternative wisdoms and enters narrower entrance (Bong, 2003, p. 77). My experience encourages me to conduct cultural studies related to the exclusion of OPUD from Holy Communion Sacrament. Through this route I also encourage my colleagues as GKJ congregational leaders and other synods to pay attention to the twin actions shown by 
Robert Schreiter in designing local theology, which is to examine culture and church traditions (Schreiter, 1991, pp. 47-56).

\section{Definitions on Sacrament}

Sacrament is an important ritual, as it is considered as the pinnacle point or fire point of church life and witness (Feineren \& Vischer, 1975, p. 301). One would feel special aura while working in it. This perspective is in contrast with the fact that in sacrament celebration ritual where two aspects of the commandment meet. The congregation would not only listen to the Commandment, but they could also see and even touch, hold, and swallow it. The commandment is practiced visibly within the available signs. The commandment goes into our body through eyes, nose, mouth and merge into our flesh and body.

There are various interpretations of the essence of the two Sacraments among Christians throughout the century. Moltmann stated that baptism is the eschatological sign of starting out from selfcentered life (ego-centric) to start Godcentered (Christ) and human-centered (Christo-centric) life. Eschatological sign of starting out does not expire. There would be no one who only lives for himself. He would live for God and others. With baptismal, this someone would participate in the parade of marching congregations to the end of the world to witness Easter and Pentecostal. Whereas, Holy Communion is the eschatological sign of being on the way. Baptismal is the unique sign of grace while the Communion is repeatable sign of hope. This is the intrinsic meaning of baptism sacrament. In baptism, an individual is unified with the Christ's body through its confession, while in Holy Communion, the membership is strengthened by participating in the banquet in God's table (Moltmann, 1977, p. 243).

As a theologian rejecting the separation practice of sacraments in the missionary era, I.H. Enklaar proposed the understanding of baptism and communion with an interesting metaphor. He believed that "baptism was a sign and stamp of salvation and forgiveness of sins by Christ's blood and redemption by the Holy Spirit and purification as Christ's people (Enklaar \& Siahaan, 1978, p. 14). His explanation for the understanding encouraged people to think of transplantation process in agriculture. Christ was symbolized as the main root while the baptized candidates was symbolized as other trees to be merged with the main tree. The transplantation process was started by cleaning the young shoots 
from dirt, then they were finally merged into the new parent plant.

Similarly, the Holy Communion was symbolized as a moment where the new young shoots are given foods and drinks to strengthen them. Delaying the feeding process for the young shoots will have bad impacts. As explained by Enklaar, in the first congregational, the baptism service given to the converts is quickly followed by Holy Communion sacrament because the communion will be strengthened and determined by Christ's spiritual presence through bread and wine on the table. By enjoying the specially served foods and drinks, the new converts would feel more strongly that they are a part of unified spiritual body, the Church. They would also feel strong tie with God and brothers(Enklaar \& Siahaan, 1978, pp. 1213). Related to this idea, Moltmann emphasized that the Holy Communion is not a place to employ the Church's discipline. This should be a venue where they could freely celebrate the resurrection of Christ (Moltmann, 1977, p. 245).

The objection explained by Enklaar on the separation of sacrament in missionary era was summarized into three points. First, serving baptism to someone then delaying the communion by saying that one's knowledge and understanding of Christ's life, sacrifice, and death is still lacking would convey the message that faith would only about knowledge and intelligent and rational understanding. This would imply that Christianity is about the memorization of verses, our Father in Heaven, Ten Commandment, and Apostolic Creed, and will create nameplate-Christianity. Second, the separation of baptism and sacrament would humiliate the dignity of Sacred Baptism that is not blessed and would only give wrong impression and understanding of the real meaning of Holy Communion as sacred and magical event which would bear fruit when it was held. Third, decreasing the requirement for baptized until the most minimum point and increasing the requirement for Holy Communion would make the celebration of Holy Communion would be based on humans' kindness and achievement rather than God's gratification (Enklaar \& Siahaan, 1978, pp. 120-123).

Enklaar showed that the prophets would not think of a requirement where the congregation should be in a higher level of religious understanding and to show more dignified behavior to be allowed in the Holy Communion. $\mathrm{He}$ believed that by participating in important moments, where people with low level of understanding and 
knowledge of Christ and who were still fighting to dismiss their old habits, would receive stronger spiritual energy and richer understanding and comprehension of Christ's life, suffering, and death (Enklaar \& Siahaan, 1978, p. 12).

\section{Analyzing Church Tradition on Children in Holy Communion}

According to Robert Schreiter, in the effort to design local theological construction, there are two therapies needed to be conducted. The first therapy is to examine the church traditions. It is conducted to raise awareness of local churches regarding shallow understanding of traditions. Some missionaries often have their personal agenda to make new churches as the replica of their old churches. The pattern of domination and conquer of new churches in monoculture agenda from the home country of the missionaries is considered as unchangeable law. The church tradition is used to legitimize such agenda (Schreiter, 1991, pp. 53-54). The implementation of adulthood politics to determine the participants of Holy Communion Sacrament becomes an example of domination and conquer agenda. If one to carefully examine the church traditions, it is clear that the exclusion of children from the sacrament is a form of subjugation of Bible messages.

We do not find explicit statement in PB on the participation of children in Holy Communion. However, there are many references inferred for this. The Holy Communion Sacrament as commanded and exemplified by Jesus Christ, was rooted from Israeli Passover to celebrate the exodus of Israelis from Egypt. The most important characteristic in this ritual is family celebration. It is impossible to ignore the children. The participation of children in Israeli Passover, by eating unleavened bread and drinking wine is explicitly stated in Exodus 12:26 and Deuteronomy 6:20. Children might only keep asking questions regarding the meanings of such decision if they become attendees in the Holy Communion.

There are three common reasons of church tradition to exclude children. First, from Paulus: "One should test oneself before drinking and eating from the grail" (I Kor. 11:28). Children, who are still in imitating phase, could not test themselves. Furthermore, Paulus also emphasizes that one would need complete understanding of Christ's body, symbolized in bread and wine (1 Kor. 11:29). Second, bread and wine in Holy Communion should be distinguished 
from the bread and wine found in our daily lives, because they are symbols in the Holy Communion. They are not merely element. Children have not reached the phase where they would understand such metaphor. Third, the determination of Holy Communion is meant to remember God's death and His resurrection. Children who have not received intricate Christian teachings and values would encounter difficulty to remember such thing. They need to be taught and guided to understand Christ's sacrifice in order to participate in the Holy Communion. Therefore, excluding children from Holy Communion is not discriminative act, and it does not contradict the belief that Holy Communion worth more than Baptism Sacrament. This is an important point because Holy Communion is a sacred action, and not merely social ritual.

Careful examination on the interpretation of Bible also encourages the church to reexamine its teaching regarding this issue. First, related to Paulus' warning in Corinthian. There are two points inferred by Paulus regarding self-test: in substantial and practical aspect. The substantial aspect refers to discord in Corinthian congregation. Paulus uses I Corinthian 11 to solve this discord. Therefore, if there are people who eat bread and drink wine referring to Christ's flesh and blood, but they still stir discordance, or in other words they are not willing to return to unity, they have sinned on Christ's flesh and blood. Through its practical point, Paulus uses Holy Communion ritual to strengthen the social awareness and solidarity from those who are economically able for the poor. There should be no discrimination in Holy Communion. If someone eat too much in the event preceding Holy Communion, and those who come late do not receive proper food, it could become a disgrace. The Advice in I Kor. 11: 28 does not talk about the presence of children, it is against discordance and discrimination.

The following point will explain the second and third reason that relates it with children's understanding and introduction on the meaning of sacraments. It is a mistake if we determine high level of knowledge and understanding as the requirement to participate in the Holy Communion. I.H. Enklaar showed that in apostle era, there is no special requirement that they should reach certain level of understanding of Christianity faith before they could attend the Holy Communion (Enklaar \& Siahaan, 1978, p. 12). The explanation by Marcus Borg in the following is needed to be 
underlined. Requirement for communion with God is not determined on "knowing and strong belief of God, but experiencing and knowing God throughout one's life in daily life"(Bong, 2003, p. 48). Should we also remember that the right and in-depth knowledge and understanding can be acquired through the participation of these rituals? The most effective method to understand and comprehend the essence of sacraments is through direct participation. This is the educational method of Jews on the meaning of Passover.

When I studied in Netherlands, we found many children who came with their parents on Holy Communion. My wife and I always sat next to a family with three children who were 5-9 years old. Every time the priests shared bread and wine, the parents explained the meaning of such rituals to their kids. I observed that the two older children opted to eat bread and drink wine. One day, I asked one of them and he gave me really interesting answer: "Father and mother said that the bread and wine is Christ's flesh and blood. I eat them because I want Jesus to live within me."

This example highlights the importance of participation and parental guidance. Even though Holy Communion Sacrament has been formalized as church ritual in general context, parental role should not be taken lightly and even taken over by the institutional church. Parents should be the first and main religious educator for children, including to explain the meaning of sacrament. There is another interesting reference in the Bible. Circumcision is mentioned to be the prototype of baptized is given to the children when they are eight days old, even before they understand it. Through the circumcision, they have become a part of congregational members and therefore they are included in the Israeli Passover, which becomes the prototype of Holy Communion Sacrament.

\section{Dissecting PPA and GKJ Ecclesiology}

The fact that GKJ still debated over whether children are feasible to be included in the Holy Communion Sacrament along with adult congregation members due to some unreasonable church traditions is shocking and confusing for me because I found two enlightening points in PPA-GKJ and GKJ ecclesiology. The first point is regarding GKJ understanding or ecclesiology of church. The second point is GKJ understanding on Holy Communion Sacrament as the symbol of God's family life. I want to get into detail of these two points. 
Regarding ecclesiology. As understood by GKJ that a religious revolves around Jesus (Sinode, 2005, p. 75). Rev. Andreas Untung Wiyono emphasized that this ecclesiology concept is formulated to separate the church from other organizations, considering that the church core values is Jesus Christ (Wiyono, 2008, p. 7). This is not to reject the understanding that church does not need or is not allowed to be managed based on worldly values. This understanding further highlights that the church management based on worldly values to realize the church's purposed is needed but should be continuously evaluated based on the core values (Wiyono, 2008, p. 9).

For me, this ecclesiological understanding have positive meaning on the participation of children. I was surprised and annoyed when I read question number 137 of PPA-GKJ: "Who are allowed to participate in the Holy Communion?" Answer: "Any adult who were baptized or whoever claiming to believe and is not in special guidance." Its ecclesiological understanding provides a standpoint of free participation, but there is an inconsistency when the ecclesiology is explained in the requirement of participants in Holy Communion Sacrament. What is happening?
My first impression was: the exclusion of children in many churches in Indonesia, including GKJ, showed that children were included in the silenced group, they are considered as stupid, undeserving, and so on. By implementing Edwin Ardener's anthropological feminism theory, the politics implemented in these churches is adulthood politics. Children who believed in Christ and received their baptism are marginalized and silenced (Moore, 1998, p. 12). The Holy Communion is exclusively for adults and those who have higher level of knowledge and understanding.

The core value of GKJ ecclesiology is Jesus Christ, but there is another agenda within the practice. The Bible clearly shows criticism by Jesus on adulthood politics practiced by His students who conducted selection on those who were allowed to get close to Jesus and received His blessings. After criticizing, Jesus allowed children to approach Him. He even hugged them and placed His hand on top of their heads and blessed them (Mrk. 10:16). Instead of adulthood politics created by His students and Jewish society, Jesus introduced equality politics, not only based on gender but also on age. Jesus did not demand prerequirement fulfilments, he only wanted 
their commitment to live life with new quality based on the blessing they received.

The question and answer on number 137 of PPA-GKJ also required a baptized adult and has no problem regarding their faith. Besides making elitists claim on adults, the answer conflicts with the example practiced by Jesus recorded in Matthew 18:1-4. Jesus called a child and placed the child among them and he said: "Truly I tell you, unless you change and become like little children, you will never enter the kingdom of heaven." This demonstrative action was done by Jesus to answer the debate amongst the students on "Who is the biggest in the Kingdom of Heaven?"

Now, regarding the meaning of Holy Communion. According to PPA-GKJ question number 135 , the answer number two stated that: "Through communal food and drink that symbolizes the family of God." The Family of God symbolizes intimate brotherhood, personal and close amongst its congregational members. Church is a community of mutual affection, mutual sharing, and bear the burden (Sider, 2005, p. 154). All Christians are children while God is the Father in the family (Gal. 4:4-7). As children of Father, they are the heirs of Christ (Rom. 8:16-17). In this family, Jesus Christ is the oldest son and our brother (Ibr. 2:10-13).

Brotherhood is considered as worldly. It transcends the limitations made by humans, including religion. The brotherhood is no longer based on biological relationship, it is also based on faith (Gal. 4) and willingness to follow God's command (Mrk 3:35). This image also emphasizes that we do not personally choose who can become a part of the family. God as Father would determine this. $\mathrm{He}$ would call everybody, Jews, non-Jews, men, women, big or small, master or servants, rich or poor, Christians or non-Christians into the family. If communal dining in Holy Communion symbolizes the family of God, why should we spend our energy in debating whether children should be allowed in the event while God has determined that they are a part of the family on the Sacrament of God's Table? If the practice of GKJ that is clearly based on the core values of church is still debated, then it is clear that there is another agenda within its practice. What is that agenda?

\section{Analyzing Javanese People's Traditions}

In addition to examining the church tradition in the effort to generate local 
theology construction, examining the local culture is an equally important additional task, according to Robert Schreiter. The purpose of such action is to understand the configuration of main values, meanings, needs, and interest of a culture. Examining a culture means capturing the essence of a culture holistically and its entire complexities in order to make a decision whether one would need to include Christ within the culture or if Christ is already included in the culture? (Schreiter, 1991, pp. 47-48). Culture romanticism will always be a danger, which could be in the form of overdosed admiration of cultural values that it blinds the awareness of sinful acts within the values. In theology, the combination of cultural romanticism and shallow understanding of church tradition would diminish the awareness of other agenda incompatible with the church core values. The exclusion of children from Holy Communion Sacrament popular in GKJ shows that GKJ prefers to uphold Javanese culture rather than the agenda within the Gospel of the God's Kingdom.

Slametan or wilujengan is a main and important ritual of all rituals and ceremonies in Javanese religious system, as stated by Cliffort Geertz (Geertz, 1960). The most dominating characteristic of slametan was family party (Koentjaraningrat, 1984, p. 344). There is clearly a similarity with Jewish Passover. The party is started by a short opening speech by the host to describe the purpose of such party, gratitude for the attendees and apology for any errors and mistake happening in the event and the foods. After that, the prayer is led by a religious person or one of the relatives. It is then followed by dining after the prayer. The guests leave the host's house after $d h i k r$, or collective prayer by reciting la'illaha illallah repeatedly for more than forty five minutes to an hour. They will also return home while carrying foods prepared by the host. Male adults become the main actor in this party, despite the fact that the women play more important role in preparing it for example deciding the date, the guests, food catering, and whether they need to hold the party. In other words, slametan employed adulthood politics. Children are excluded from this party despite it is a family party. How so?

In Javanese families with traditional orientation, since the father holds higher position compared to the children, they do not want to have children in such party. If the father receives a guest, he will forbid his children going to where the guest is sitting. They need to leave the room and will come 
in when they are summoned (Koentjaraningrat, 1984, pp. 244-116). The children are obliged to talk to their parents in formal language (krami). The way Javanese people guide their children is to let them to explore their world, without guidance, as long as they did not disturb other people. The parents will intervene if such things happen. There are six model of children education in traditional Javanese family: (1) by diverting children's attention from forbidden actions; (2) by educating children; (3) by scaring them with ghosts and monsters; (4) by promising candy or present; (5) by punishing them; and (6) by making them feel embarrassed (Koentjaraningrat, 1984, p. 244). Such models become the main cause why children tend to become shy, indecisive, dependent, and lack of initiative when they are involved in the society (Brouwer, 1979, p. 96).

The relationship pattern of parentschildren that is seen as master-servant and leader-subordinate in traditional Javanese society has changed into friendship in modern Javanese society. Children have higher freedom to express their feelings, desire, and opinions spontaneously, informally, familiarly, and casually. With this new pattern, children's attitude would develop more healthily, strongly, creatively, and openly (Brouwer, 1979, pp. 94-97). In modern Javanese family and almost all other ethnics in Indonesia, the relationship pattern of parents-children has shifted from vertical pattern to horizontal pattern, where adults (parents) and children are treated as equal. However, this equality has not been articulated completely in the church, therefore, we could find the exclusionary practice in Holy Communion Sacrament. Churches in Indonesia exist in modern times where it respects individual rights and obligations, but some churches still retain their ethnical, traditional-feudal belief by employing adulthood politics in Holy Communion sacrament.

John Titaley saw that the cause of ethnic, traditional-feudal nuance within the church was mainly caused by the fact that Indonesian churches still have incomplete understanding of the social condition in Indonesia (Titaley, 2013, p. 146). Actually, the narrative of Indonesian-ness consists of two standpoints: primordial (ethnical) reality focusing on pre-Indonesia situation, and national reality, which refers to the social condition after 1945. Ethnical or primordial reality is a part of reality in Indonesia. Churches in Indonesia, whom Abineno identified as ethnical or local Church (Pattiasina \& Sairin, 1990, p. 235) 
tend to establish comprehension based on ethnical and local border. They ignore national reality or is considered as less urgent, whereas, this reality has strong influence on Churches. I believe that various forms of anarchy and radicalism occurring in Indonesia right now, including the exclusion of children from Holy Communion are caused by lack of awareness and empty national reality. It becomes unknown land, where people could fill it however they want, either by filling it with traditional-feudal values or by importing Western and Middle Eastern ideologies incompatible with Pancasila and UUD 1945 (Timo, 2016, p. 77).

\section{Reflective Notes}

Excluding children in Holy Communion Sacrament is a ecclesiological product, which on one hand is built based on limited understanding of church tradition, and on the other hand based on incomplete understanding of Indonesian churches on the reality in Indonesia. In the case of PPAGKJ, we found that ecclesiological and theological foundation that might erase the stigma of children marginalization in Holy Communion. This was emphasized on the understanding that church serves as religious life centering in Jesus Christ and the essence of Holy Communion as the symbol of God's familial life. Therefore, GKJ could not completely free itself from the adult politics taking root in slametan. This is ironical because the society has changed considerably and the understanding to answer the challenges of life dynamics by focusing on horizontal relationship pattern, friendship, and brotherhood, while the church chooses to retain its vertical relationship pattern, master-servant, leadersubordinate. Jesus Christ's traits and teachings as core value are not visible in Holy Communion. The traditional Javanese cultural practices that tend to be vertical, feudalism that treats children as half-human or non-human remains dominant.

If GKJ would give discretion for children to participate in the Holy Communion, there are some steps needed to be implemented. First, conducting limited amendment on PPA-GKJ, especially question number 137. Second, strengthening parental role for educating children should be expanded, not only related to Baptism Sacrament, but also on Holy Communion sacrament. The emphasis on question number 132 of PPA-GKJ for Baptism should be copied and pasted with adjusted changes for Communion agenda. I also believe that PPA-GKJ chapter five, week 19 
and 20, which is statehood life and national sovereignty should be amended, considering theological perspective of GKJ about Indonesia and the fact that Indonesia is not unified yet. These suggestions are from my perspective, but if I need to include Bambang Subandrijo's study on GKJ's understanding of God that still does not cover the needs in Indonesia (Subandrijo, 2016, pp. 67-72), I am worried that limited amendment would not suffice and it would need expanded amendment on PPA-GKJ.

I have objections on the paedocommuni in some Indonesian churches I saw in the website pictures. The children are gathered in a room then the pastor or priest serves them wine and bread. I am not comfortable with such sight. We know that Israeli Passover and slametan (Indonesian traditional thanksgiving celebration) is familial celebration, which means the children are not excluded. They attend the celebration with their family and parents. I believe that if they are separated from their parents in Holy Communion, the moment of faith education would become ineffective. It would only diminish the sacredness of such celebration into mere children gathering where they eat bread and drink wine.

\section{CONCLUSION}

At the end of this paper it is worthy to draw a short conclusion. As christian church in a definitive social context, namely Javanese society, GKJ is struggling to built an intensive dialogue between Gospel and the culture of her own members. According to the Gospel, Jesus wellcame the children to the kingdom he proclaimed. More than that, Jesus explisitly mentioned that the condition to enter into the kingdom is to live a life as one of the children (Luk. 18:16). Surely, GKJ is acquintance with this verse and continualy tries to apply this verse in all church lifes and ministries. In the other hand, GKJ also tries to live as a church of Javanese people. In old Javanese tradition, children was regarded as unmature. The were treated differently from mature one. Nowadays children are no more treated as a second class person. Almost in all life activities children get equal attention as other member of the society. It is expectedly if GKJ allowes the children of her members which have received baptism to participate in eating bread and drinking wine that simbolize the body and the blood of Christ poured out as the removal of our sins. What is taking place nowadays in GKJ is quite different. There are more than $75 \%$ local congregations of GKJ that do not permit the 
children to join thier parents in celebrating the holy communion. They still hold fast to the old Javanese culture. It is an awkward but real. There are lot of theological works to be concluded by the young generation of GKJ's church leaders in order to make the yeast of Gospel transforms people own culture in building a community of peace for all.

We have here one example, namely how GKJ exercises a double struggle: struggling to listen carefully to the word of God proclaimed in the Bible at one hand, and at the another hand how she remains embedded in cultural inheritance of Javanese people.

H. Richard Niebuhr in his wellknown books titled: Christ and Culture, mentioned five paradigmatic christian attitudes toward culture (Niebuhr, 1985). He explicitly mentioned that tranforming culture by the Gospel is what the Church has to perform. It is a contribution the Church overs to build a better society for all. This article shows that GKJ is still far from that poin. Instead of struggling to present the Gospel as the renewal of Javanese culture, GKJ prefers to maintain old Javanese attitude toward children in celebrating the Holy Communion.

\section{BIBLIOGRAPHY}

Bong, M. J. (2003). Kali Pertama Jumpa Yesus Kembali. BPK Gunung Mulia. Brouwer, M. A. W. (1979). Kepribadian dan perubahannya. Gramedia.

Enklaar, I. H., \& Siahaan, P. (1978). Baptisan massal dan pemisahan sakramen-sakramen. BPK Gunung Mulia untuk Perhimpunan SekolahSekolah Theologia di Indonesia .... Feineren, J., \& Vischer, L. (1975). Nieuwe Woorden over God, Wereld en Kerk. Schetsvan gezamelijkchristelijkgeloven. Herder Verslag.

Geertz, C. (1960). The Javanese Kijaji: The changing role of a cultural broker.

Comparative Studies in Society and History, 2(2), 228-249.

Koentjaraningrat. (1984). Kebudayaan Jawa. PT Balai Pustaka. Moltmann, J. (1977). The Church in the Power of the Spirit. SCM Press, Ltd.

Moore, H. L. (1998). Feminisme Dan Antropologi (Penerjemah: Tim Proyek Studi Jender dan Pembangunan FISIP UI). Jakarta: Penerbit Obor.

Niebuhr, H. Richrad. (1985). Kristus dan Kebudayaan. Jakarta: Petra Jaya. Pattiasina, J. M., \& Sairin, W. (1990). Gerakan Oikumene. Tegar Mekar di 
Bumi Pancasila. BPK Gunung Mulia.

Schreiter, R. J. (1991). Rancang Bangun

Teologi Lokal. BPK Gunung Mulia.

Sider, R. J. (2005). The scandal of the

evangelical conscience: Why are

Christians living just like the rest of the

world? Baker Books.

Sinode, G. K. J. (2005). Pokok-Pokok

Ajaran Gereja Kristen Jawa. GKJ

Doctrine of Principles Salatiga.

Subandrijo, B. (2016). Yesus Sang Titik

Temu dan Titik Tengkar. Jakarta: BPK

Gunung Mulia.

Timo, E. I. N. (2016). Meng-hari-ini-kan

Injil di Bumi Pancasila. UKSW.

Titaley, J. A. (2013). Religiositas di alinea

tiga: pluralisme, nasionalisme, dan

transformasi agama-agama. Satya

Wcana University Press.

Wiyono, A. U. (2008). Eklesiologi GKJ.

Sinode Gereja-gereja Kristen

Indonesia. 